\title{
THE UNITED STATES PATENT OFFICE
}

\author{
LAWRENCE C. KingsLaND*
}

I

Constitutional Provision and the Furst Patent Act

When the Constitutional Convention met in Philadelphia in May, 1787 , one of the basic problems for solution was to determine whether a strong national government was to be formed or whether a confederation of the states was to be the basic framework of the new government. When once the decision in favor of the former plan was, adopted, the Convention had little difficulty in determining that the grant of letters patent for inventions was a national function.

Many of the states before the adoption of the Constitution had, by special legislative acts, granted letters patent for inventions, following the historical precedent of such grants by the sovereigns in England. ${ }^{1}$

In England all special monopolies granted by the Crown were declared illegal by the Statute of Monopolies, passed in 1623 during the reign of James I, but that act specifically excepted the grant of letters patent to true and first inventors for the sole right of making and working new manufactures within the realm, for a term limited to fourteen years or less. ${ }^{2}$

It is not surprising, with this historical background, therefore, that when the final draft of the Constitution was adopted by the Convention in September, I787, it contained the specific provision that:

Congress shall have the power ... to promote the progress of science and useful arts, by securing for limited times to ... inventors the exclusive right to their . . . discoveries. ${ }^{\text {B }}$

The framers of our Constitution, with rational foresight, viewed the grant of limited monopolies to inventors primarily as a means of promoting the industrial development of the new republic and emphasized this primary objective by the phraseology of the constitutional provision.

The means to accomplish this primary objective was the provision for securing to inventors, as a reward or incentive, the exclusive right to enjoyment of their discoveries. The profit motive to the inventor was the spur to activity of inventors. The constitutional provision, therefore, not only recognized that the public interest would be served by the grant of letters patent, but it also recognized that, as a matter of incentive and of common justice, one who contributed to the public wealth of

- Commissioner of Patents.

${ }^{1}$ Federico, State Patents, 13 J. Pat. Ofr. Soc'y I66 (I931).

2 I JAC. I, c. $3, \$ 6$.

U. S. Const. Art. I, $\$ 8$. 
tangible knowledge in respect of the useful arts should be remunerated for his contribution.

The requirement that the term of the grant should be limited and should be available only to inventors for their discoveries clearly distinguished the nature of the grant from the odious monopolies for old things which, prior to the Statute of Monopolies, had been granted by the sovereign in England.

Pursuant to the Constitutional provision, the First Congress passed "An Act to promote the progress of useful Arts." This act became effective on April I0, I790. The title of the statutory enactment defined the primary objective as the promotion of the progress of useful arts.

Chief Justice John Marshall, at a later date, speaking for the Supreme Court in Grant v. Raymond, clearly stated the philosophy underlying our patent system in the following language:

To promote the progress of useful arts is the interest and policy of every enlightened government. It entered into the views of the framers of our constitution; and the power "to promote the progress of science and useful arts, by securing for limited times to authors and inventors, the exclusive right to their respective writings and discoveries," is among those expressly given to congress. This subject was among the first which followed the organization of our government. It was taken up by the first congress at its second session, and an act was passed authorizing a patent to be issued to the inventor of any useful art, \&c., on his petition, "granting to such petitioner, his heirs, administrators or assigns, for any term not exceeding fourteen years, the sole and exclusive right and liberty of making, using, and vending to others to be used, the said invention or discovery." ... It cannot be doubted that the settled purpose of the United States has ever been, and continues to be, to confer on the authors of useful inventions an exclusive right in their inventions for the time mentioned in their patent. It is the reward stipulated for the advantages derived by the public for the exertions of the individual, and is intended as a stimulus to those exertions. The laws which are passed to give effect to this purpose ought, we think, to be construed in the spirit in which they have been made; and to execute the contract fairly on the part of the United States, where the full benefit has been actually received, if this can be done without transcending the intention of the statute, or countenancing acts which are fraudulent or may prove mischievous. The public yields nothing which it has not agreed to yield; it receives all which it has contracted to receive. The full benefit of the discovery, after its enjoyment by the discoverer for fourteen years, is preserved; and for his exclusive enjoyment of it during that time the public faith is pledged. ${ }^{6}$

By the terms of the first statutory enactment one who invented or discovered "any useful art, manufacture, engine, machine, or device, or any improvement thereon not before known or used," upon application by petition to a commission comprising the Secretary of State, the Secretary of War, and the Attorney General, was entitled, under conditions provided in the act, to the grant of letters patent securing to him "the sole and exclusive right and liberty of making, constructing, using and vending to others to be used," his invention for a term not to exceed fourteen years.

$$
\text { i Stat. rog. } \quad{ }^{6} 6 \text { Pet. } 218 \text { (U. S. } 1832 \text { ). } \quad{ }^{\circ} \text { Id. at } 24 \text { I, } 242 .
$$


The petitioner, as a condition of the grant, was required to file with the Secretary of State a written specification, drawings, and in appropriate cases a model. These disclosures were to be of such a nature as to enable the asserted invention to be distinguished from things before known and used; and to enable others skilled in the art to make and use the invention upon the expiration of the term of the grant, and thereby to make available to the public the full benefit of the invention.

The Congress recognized that a legal grant of a patent was invested with the quality of property, and provided for the recovery of damages for a legally established invasion of this property right.

The commissioners or any two of them were empowered to determine the validity of the basis of the petition for the grant, and if they "deemed the invention or discovery sufficiently useful and important," letters patent in the name of the United States were granted. The decision of the commissioners was final, subject only to the power vested in the federal district courts, by an action instituted within one year from the grant, to cancel the letters patent.

It is interesting to note that the original commission was constituted of Thomas Jefferson, Secretary of State, Henry Knox, Secretary of War, and Edmund Randolph, Attorney General. This body of cabinet officers was variously referred to as the "Patent Commission" or "Patent Board."

As a result of the vesting of the administrative functions under the act within the jurisdiction of the Department of State, Thomas Jefferson took the lead in the activities of the board, and because of his personal interest in scientific and technical matters, which he applied to the administration of this first Patent Act, he greatly influenced the initial development of the American patent system. He may, therefore, be regarded from a historical point of view as the first administrator of the system.

The full extent of the examination conducted by the commissioners can only be conjectured. They investigated the papers for completeness of disclosure, and presumably examined whatever sources of technical information were available. Statements made much later ${ }^{8}$ suggest that a few elementary notions of the legal concept of invention may have been glimmering.

The system operated under the Act of 1790 for approximately three years. During this period only fifty-seven letters patent issued. While the system was thus productive of only a very limited number of patentable inventions, a very general foundation for the patent system was laid, which finally evolved into the structure of the system as it is now known.

\footnotetext{
TFederico, Operation of the Patent Act of 1790, I8 J. PAT. OFF. Soc'Y 237, 238 (1936).

${ }^{8}$ Letter of Jefferson to McPherson, August 13, 1813, 6 Writings of Thomas Jefrenson 175, 180 (Washington ed, 1854 ).
} 
II

\section{The Patent Act of I793}

The vesting of the power to grant patents in the commission, composed of the three cabinet members, placed a heavy burden upon these officials. Since the act required that a factual and quasi-judicial determination be made by the commission before the grant of a patent, and since these duties were incidental to other official duties, delays in the consideration of such petitions resulted. The personal administration under the act required time and energy of these top-level administrative officials of the Government which were needed for more pressing matters of state.

As a result, a number of proposals for changes were presented to and considered by the Congress, eventually resulting in the enactment of an entirely new patent act on February 2I, I793. ${ }^{9}$ This new legislation radically changed the basis for the grant of letters patent.

The requirement for a determination that the subject matter was "sufficiently useful and important" to justify the grant was omitted from the new act. This caused a fundamental change in the system, from one based on examination of the proposed invention to one of simple registration without examination. The granting of petitions for the issuance of letters patent became largely a clerical function. These administrative functions were left in the office of the Secretary of State, and the processing of the petitions followed a very simple procedure.

Upon the filing of a verified petition in the office of the Secretary of State, together with a full disclosure, that office prepared letters patent and referred them to the Attorney General for a pro forma examination. The only requirement was that the Attorney General find that the letters patent conformed to the provisions of the act, whereupon the patent, signed by the President, was issued to the petitioner as a matter of course.

The routine grant of letters patent under the Act of 1793 was not absolute, however, because patents issued under its provisions were subject to "repeal" by action instituted in a federal court within three years of the date of the grant. If one attacking the patent by such process was able to show that the patent was procured "surreptitiously or by false suggestion," or that the patentee was not "the true inventor or discoverer" of the subject matter purportedly covered by the patent, the court was empowered to cancel the grant.

The act also attempted to clarify the negative character of the right secured by the grant-that is to say, the right was one to prevent others from "making, constructing, using and vending" the subject matter of the patent for the term of the grant, and the grant did not confer the right on the patentee affirmatively to make, use, or sell if such action would interfere with rights of others. The right to exclude others, however, was in terms referred to as "property."

The statute also dealt with the subject of interfering applicants for the grant of

'I STAT. 318. 
patents relating to common subject matter. The solution offered by the act was a provision for a board of arbitrators to decide the disputed rights between interfering parties. This provision was to supply an omission from the original legislation which had given rise to questions of priority of rights between applicants for common subject matter. While the original act had omitted any specific provision, there may have been inherent power in the commission to determine the question of priority, but the new act made the provision specifically, and set up the practice of having the issues determined by the independent board of arbitrators. These provisions foreshadowed the later interference practice, as will appear when that phase of the administration under current practice is examined.

The act also included a requirement that an applicant relinquish rights under any state grant obtained prior to the adoption of the Constitution, as a condition of the grant of a federal patent.

During the period from the passage of the Act of 1793 until 1802 the administration of the act was conducted as part of the work of a clerk or clerks in the Department of State. In the latter year James Madison, then Secretary of State, appointed one person, who subsequently became known as the Superintendent of the Patent Office, to handle the patent work. In a short time, as the volume of work grew, the Patent Office developed as a distinct bureau in the Department of State under the designated administrator.

As a result of the loose provisions of the Act of 1793 , it can well be imagined that operations under it were never satisfactory. Many issues arose from duplication of grants for common subject matter as well as many disputes regarding originality. Many frivolous disclosures were the basis of grants which gave rise to controversies over subject matter of little interest. The complexity and the confusion that the legislation generated imposed a heavy burden on the parties to patent litigation, and there was strong pressure from Congress, as well as from the public generally, for a revision of the law.

It was very clear that the registration system provided by the legislation was wholly unsatisfactory, and it was evident that in its practical working it was contrary to the original theory that there should be some scrutiny before the grant of a patent. While these conditions were recognized, Congress was slow to change the basis of the patent grant since there were some who held to the view that an incentive for a wide scope of disclosure to aid industry would result from a policy of granting patents freely; but it became more and more apparent that the system was not workable, so that finally, early in 1836 , a committee of the Senate was appointed to make a thorough study of the system. This committee reported to the Senate and introduced a new bill embodying the changes deemed necessary to accomplish the reform of the patent law. ${ }^{10}$

The report of the committee clearly reflected the conditions that existed and, as a

${ }^{10}$ SEN. Doc. No. $33^{8}, 24^{\text {th }}$ Cong., Ist Sess. $(1836)$. 
contemporary document, reveals the abuses that had grown up under the registration system. In part this report was as follows:

Under the act referred to, the Department of State has been going on, for more than forty years, issuing patents on every application, without any examination into the merits or novelty of the invention. And the evils which necessarily result from the law as it now exists must continue to increase and multiply daily until Congress shall put a stop to them. Some of them are as follows:

I. A considerable portion of some of the patents granted are worthless and void, as conflicting and infringing upon one another, or upon public rights not subject to patent privileges, arising from either a want of due attention to the specification of claim, or from the ignorance of the patentees of the state of the arts and manufactures, and of the inventions made in other countries, and even in our own.

2. The country becomes flooded with patent monopolies, embarrassing to bona fide patentees, whose rights are thus invaded from all sides; and not less embarrassing to the community generally, in the use of even the most common machinery and long known improvements in the arts and common manufactures of the country.

3. Out of this interference and collision of patents and privileges, a great number of law suits arise, which are daily increasing in an alarming degree, onerous to the courts, ruinous to the parties, and injurious to society.

4. It opens the door to frauds, which have already become extensive and serious. It is represented to the committee that it is not uncommon for persons to copy patented machines in the model room; and, having made some slight immaterial alterations, they apply in the next room for patents. There being no power to refuse them, patents are issued of course. Thus prepared, they go forth on a retailing expedition, selling out their patent rights for States, counties and townships, to those who have no means at hand of detecting the imposition, and who find, when it is too late, that they have purchased what the venders had no right to sell, and which they obtain thereby no right to use. This speculation in patent rights has become a regular business, and several hundred thousand dollars, it is estimated, are paid annually for void patents, many of which are thus fraudulently obtained. ${ }^{11}$

As a result Congress passed the Act of ${ }_{1} 836$ in substantially the form submitted by the Senate Committee. This act became effective on July 4 of that year. ${ }^{12}$

\section{III}

\section{The Patent Act of 1836}

The new act specifically provided for the establishment of a Patent Office, created as a separate bureau within the Department of State, under a Commissioner of Patents appointed by the President by and with the consent of the Senate. The act definitely established a complete examination system and provided procedure for the operation of such a system. The determination of utility, novelty, and patentability of the disclosures became the primary function of the Patent Office. The decision to accept or reject applications was based on these criteria. The objective was to provide an adequate consideration of each application to the end that patents issued under such a system would have at least prima facie validity.

$$
{ }^{12} \text { Ibid. }
$$$$
125 \text { STAT. II7. }
$$ 
The act reincorporated the requirement that the applicant furnish a specification, drawing, and model (if practicable), together with a verified statement of original inventorship. If prior invention, publication, or use developed as a result of the examination, the application was subject to rejection, but the applicant was entitled to a notice of a rejection together with grounds thereof.

An appeal was provided to a board of three disinterested persons appointed by the Secretary of State, one of whom, if practicable, was to be an expert in the particular art. This board sat as a board of arbitration to decide issues between the appellant and the Commissioner, and had authority to affirm or reverse the Commissioner's decisions.

Provision was made for interference proceedings, with jurisdiction in the Commissioner, in the first instance, to determine the issue of priority between rival claimants for a patent. The Commissioner's decision was subject to review by a board constituted as in ex parte appeals.

The decision of the board was final in ex parte cases and in interference cases between applicants. In an interference between an application and an unexpired patent the decision of the board was subject to review in a federal court by bill in equity. This original equity review of Patent Office decisions was provided only if there were adverse parties and one or more patents were involved.

The Commissioner was authorized to reissue patents in cases in which the original patent was defective, either because of insufficient specification or of overstatement of claims, provided the errors arose without fraudulent intent on the part of the applicant.

The original term of the patent grant was for fourteen years, but upon application to a board comprising the Secretary of State, the Solicitor of the Treasury, and the Commissioner, and upon sufficient showing, the term could be extended for an additional seven years by the board.

It is apparent that the system established by this forward-looking legislation provided the first comprehensive one based upon a rational theory for the establishment of patent rights in cases in which the applicant was justified in securing a grant, and of denying the assertion of such rights for the protection of the public for failure to comply with the provisions of the act. For the first time logical provision was made for the performance by the Patent Office of the dual function of rewarding a true inventor by the allowance of an application, but also insuring that the public would be protected by rejection of unfounded claims to subject matter that was in the public domain.

The Act of 1836 may, therefore, be regarded as creating the foundation upon which our present patent system was erected. In the basic principle of examination before grant the legislation created a pattern that was later followed by modern industrial countries which hold to the theory that the public interest is advanced by rewarding inventors who have in fact contributed to the public welfare a new and useful concept, and who have provided tangible and workable means for making 
available such means to the public after the limited period of exclusive enjoyment by the inventor or by those holding under him.

The basic American concept of examination before grant, embodied in the Act of 1836 , was retained in all subsequent legislation, which, on this score, was primarily directed to changes seeking to strengthen the system from the procedural point of view and to augment the personnel of the Patent Office from time to time commensurately with the workload imposed upon the Patent Office.

\section{IV}

\section{LEgISLATION AFTER $\mathrm{I}_{3} 6$}

Within the period from 1836 to 1870 there were a number of revisions and amendments of the law as defined in the Act of 1836 , but only a few of these changes have any important bearing on the fundamentals of the system.

In 1839 Congress passed an amendment affecting the right of review of the Commissioner's rejection of an applicant's claims, both in ex parte and interference cases. $^{13}$ Appeals to the board of examiners as provided by the Act of 1836 were abolished, and provision was made for appeal to the Chief Justice of the District Court of the United States for the District of Columbia. The appeal was to the Chief Justice in person, and not to the court as an appellate tribunal. The remedy by bill in equity was extended to embrace all cases in which patents were refused for any reason.

In 1842 patents for designs were authorized, ${ }^{14}$ and the examination of design applications was added to the functions of the Patent Office.

This act also provided for the marking of patented articles-with a penalty for failure to mark and for false marking.

In I848 applications for extension of the term of patents were placed under the sole jurisdiction of the Commissioner. ${ }^{15}$

In I86I, by the Act of February 18 of that year, suits in equity and actions at law arising under the patent laws were made reviewable by the Supreme Court of the United States regardless of the amount in controversy. ${ }^{16}$

On March 2, 186r, Congress passed an amendment to the patent law which included a number of important procedural changes. ${ }^{17}$

This act made provision for the taking of depositions in interference cases pursuant to rules established by the Commissioner, and vested the power in federal courts to require the attendance of witnesses by subpoena. A further important innovation was the establishment of a permanent Board of Appeals, which comprised three examiners-in-chief, each of whom was required to possess competent legal knowledge and scientific ability. The members of the board were appointed by the President and were subject to Senate confirmation. This Board of Appeals constituted an appellate tribunal within the Patent Office to review decisions of 
examiners in ex parte appeals from rejections of applications and also in appeals in interference cases. The decisions of the board were appealable to and reviewable by the Commissioner of Patents himself. The review of the final decisions of the Commissioner remained the same.

This act also enlarged the term of patents from fourteen to seventeen years, but eliminated the power of the Commissioner to extend the term of the grant. Certain other changes in practice before the Patent Office were made.

During the period while the basic statutory provisions of the Act of 1836 were in force, up to 1870 , some twenty-five amendatory acts were passed. During this period there had been some conflicting interpretations of the several provisions of the statutes, and points of doubt and confusion had arisen. As a result, while there was no substantial dissatisfaction expressed in regard to the fundamentals of the legislation, there was agitation for a complete revision and consolidation in a single act of the basic patent law, culminating in the passage of the Act of July 8, $1870 .^{18}$

$\mathrm{V}$

The Patent Act of 1870

While it was the primary purpose of the Act of 1870 merely to consolidate and clarify the provisions of the existing statutory patent law, the new act did incorporate some additions relating to procedures in the Patent Office and provisions for review of Patent Office decisions, which have significance in connection with our present subject.

The Commissioner was given specific authority, subject to the approval of the Secretary of Interior, to establish rules and regulations not inconsistent with law for the conduct of procedure within the Patent Office.

The appointment of an Examiner of Interferences was authorized, whose function was to hear and determine in the first instance questions of priority of invention.

The act specifically empowered the Commissioner to refuse recognition to patent agents for just cause, and with the approval of the Secretary of Interior.

There was a change made with respect to appeals from the decision of the Commissioner of Patents, providing for appeals to the Supreme Court of the District of Columbia sitting in banc. Prior to the change, appeals in ex parte and interference cases could be taken to any individual judge of that court selected by the appellant. Thus the jurisdiction rested in the court as an appellate tribunal in such cases. The revision abolished appeal in interference cases. The remedy by bill in equity in both types of appeals remained.

\section{VI}

\section{Amendatory Acts After r87o}

The revision of the Patent Act that occurred in 1874 , as a part of the revision of federal laws, did not make any fundamental change since this was only a codification into the Revised Statutes. ${ }^{19}$

${ }^{18}$ I6 STAT. Ig8.

${ }^{10}$ Rev. Stats. $\$ \$ 440-496,{ }_{4}^{883-4936}$ (1874). 
Since 1874 numerous acts modifying the patent laws have been enacted. These have made many changes in the law as it was passed in 1870 and incorporated in the Revised Statutes in 1874 . Only a few of the changes will be noted.

In I8gI the review of decisions in infringement suits was substantially changed by the Judiciary Act, which created the federal Circuit Courts of Appeals. ${ }^{20}$ The jurisdiction of the Circuit Court of Appeals substantially reduced the number of patent cases that reached the Supreme Court.

In I893 the Court of Appeals for the District of Columbia was established ${ }^{21}$ with power to review decisions of the Supreme Court of the District of Columbia, and appeals from the decisions of the Commissioner of Patents went directly to the newly constituted Court of Appeals in ex parte appeals and also in interference cases.

In 1897 the time for response to rejections of the Patent Office was reduced from two years to one year. ${ }^{22}$

In I927 Congress abolished the appeal from the Board of Appeals to the Commissioner and restricted an applicant who had been refused a patent either in ex parte or interference case to a suit in equity in the district court with appeal to the Circuit Court of Appeals of the District of Columbia, or to a direct appeal to the Court of Appeals. ${ }^{23}$

In I927 an act was passed changing the time-limit for response to Patent Office actions from one year to six months. ${ }^{24}$

In I929 the appellate jurisdiction of the Court of Customs Appeals was enlarged to include direct appeals from the Patent Office in patent cases, and the title of the court was changed to United States Court of Customs and Patent Appeals, leaving jurisdiction in the District of Columbia Supreme Court (now the United States District Court for the District of Columbia), with appeal to the Court of Appeals, to entertain a bill in equity as an alternative remedy. In ex parte cases the applicant had the alternatives of a direct appeal or a suit in equity. In interference cases an appellant had the same choice, except that if the losing party proceeded by direct appeal the other party had the option to compel him to change to an equity suit. ${ }^{25}$

In I930 Congress extended the scope of patentable subject matter to include inventions relating to asexually reproduced distinct and new varieties of plants, other than tuber-propagated ones. ${ }^{26}$

\section{VII}

\section{Organization of the Patent Office}

Obviously, the statutory development of the fundamentals of the patent system and of the methods of procedure within the Patent Office and its relation to the courts has not dealt with the changes in personnel or internal organization of the

\footnotetext{
${ }^{20} 26$ STAT. 826 .

${ }^{23} 44$ STAT. 1335 .
}

2127 STAT. 434 .

24 Ibid.

2229 STAт. 692.

${ }^{25} 45$ STAT. I 475. 
Patent Office. The staff of the Office, which in 1836 numbered eight persons, has grown to almost two thousand. The industrial development during the history of the patent system in this country has imposed an increasing burden on the Patent Office in the examining of applications for letters patent. This, from time to time, has required changes in personnel and changes in the functions and duties performed by the various officials of the Patent Office.

The historical background of the development, however, leads to a clearer understanding of the purposes and functions of the present organization of the Office, which is a matter of current interest to those concerned with the system as now administered. This brings the discussion to the current organization of the Patent Office and to the manner in which that organization is integrated to perform the functions delegated to it under statutory authority.

The Patent Office as now constituted is a bureau within the Department of Commerce. By executive order in April, 1925, the Patent Office was placed under the general administrative jurisdiction and supervision of that Department (being transferred from the Department of the Interior, where it had been since I849), and the Secretary of Commerce, while without appellate power over the Patent Office decisions, has direct administrative control of the Office.

The Commissioner of Patents is appointed by the President by and with the consent of the Senate. The duties of the Commissioner are generally to act as administrative head of the Office. He superintends the performance of all duties respecting the granting and issuing of patents; exercises general administrative supervision over the entire work of the Office; prescribes rules, subject to the approval of the Secretary of Commerce, for the conduct of proceedings in the Patent Office, and for the recognition of attorneys and agents practicing before the Office; and generally performs such other duties as are requisite to the administration of the Patent Office in the performance of the functions assigned to it by law.

One first assistant commissioner, two assistant commissioners, and nine examinersin-chief also are appointed by the President, subject to confirmation by the Senate. The duties of the assistant commissioners are those assigned to them by the Commissioner, and when performing duties relating to the Office of the Commissioner they act with the same authority as the Commissioner.

The examiners-in-chief, together with the Commissioner and the assistant commissioners, constitute a Board of Appeals. The duty of this board is to hear and decide appeals from adverse decisions of examiners upon applications for patent. Final decisions of the Board of Appeals, as has been mentioned, are reviewable either by the Court of Customs and Patent Appeals upon direct appeal or by a civil action in the United States district court having jurisdiction. If an appeal is taken to the Court of Customs and Patent Appeals and such appeal is pending or has been decided, the remedy by a civil action is not available.

All other officers, clerks, and employees of the Patent Office are appointed by the Secretary of Commerce upon the nomination of the Commissioner of Patents. 
The solicitor and the law examiners constitute the legal staff of the Patent Office. This staff has charge of all litigation in which the Patent Office has an interest. These matters include appeals to the Court of Customs and Patent Appeals and suits against the Commissioner in the district court. This staff also investigates legal and legislative matters for the Commissioner, and performs such other duties with respect to matters coming before the Patent Office as may from time to time be assigned to the staff by the Commissioner.

The examining corps of the Patent Office as now constituted is divided into five groups, a number of divisions being assigned to each group, and each group headed by a supervisory examiner.

One of the primary duties of the supervisory examiners is to coordinate the formal procedures among the examining divisions with the objective of obtaining uniformity of action among the several examining divisions; to insure proficiency of the examining operations; to insure as far as practicable uniform application of Patent Office policies, rules, and directives; and to act on such matters of a technical nature as are delegated to them.

The examining staff of the Patent Office is divided into numbered examining divisions, currently sixty-nine, and a design division. Each division is in charge of a primary examiner and such assistant examiners as may from time to time be assigned to the division staff. One of the assistant examiners is designated as an assistant chief of a division and acts as chief in the absence or inability of the primary examiner.

The principal duties of the primary examiner of each division are to direct, review, and coordinate legal, scientific, and administrative operations of his staff; to insure the uniform observance and application of statutes, rules, decisions, directives, and policies relating to the examining operation; to develop and maintain the productivity and efficiency of operations; and to decide questions or make recommendations as required in certain specific matters referred for consideration by appropriate officials of the Patent Office. The primary examiner has responsibility for all actions on pending applications, and for allowance of patents issuing from his division. He also, through the division staff, determines the formal sufficiency of applications for patent; the legal patentability of claims submitted by the applicant, based on search of the prior art; and consideration of all matters relating to the merits of the application. As a result of such procedure he either allows or rejects claims. He institutes actions for determination of priority, and determines certain preliminary issues raised by interfering parties. If applications for patent are rejected either in whole or in part, he prepares statements, from the factual and legal aspects, for consideration of the Board of Appeals; and he performs such other incidental duties as are required for the proficient administration of the division.

The Board of Patent Interferences, comprised of examiners of interferences and assigned members, has the function of final determination within the Patent Office of questions of priority of invention decided as a result of inter partes interference 
proceedings. These proceedings include consideration of factual issues developed by depositions and are quasi judicial in nature. They are conducted under the Rules of Practice. A party against whom an adverse decision is made by the board has the right of appeal directly to the Court of Customs and Patent Appeals or the remedy by bill in equity, as in cases of ex parte decisions of the Board of Appeals, except that the prevailing party has the option to require the losing party to proceed by bill in equity.

As a part of the patent-examining operation there is included a classification group whose function it is to develop and insure the effectiveness of the application and use of a system for the classification of prior public scientific and technological art required for the search operation of the examining corps. This group also has final responsibility for insuring the uniform application of the law and practices governing requirements for the division of patent applications where claims to more than one invention are asserted in an application.

In addition to the patent-examining operations, there are numerous administrative functions necessarily incident to the conduct of the business of the Office. In general the administrative duties are performed by the Executive Office, in charge of an executive officer. The function of the executive officer is to plan, promulgate, and carry into execution policies and programs relating to administrative functions within the Patent Office. $\mathrm{He}$ is responsible for the maintenance and performance of the services to the public incident to the general responsibilities of the Office. In order to carry out these duties, the Executive Office is divided into the Financial, Personnel, Administrative Management, Administrative Services, Budget, and Patent Services Divisions. The Administrative Services Division is further subdivided into Correspondence and Mail, Office Services, Patent Copy Sales, and Manuscript and Lithograph Branches. The Patent Services Division is subdivided into Application, Assignment, Docket, Drafting, Issue and Gazette, and Scientific Library Branches.

The titles of the administrative divisions and branches are sufficiently indicative of the scope of their respective functions to reveal the purposes of the organization in the integrated operation of the Office. Generally speaking, the administrative offices deal with all of the business functions connected with the operation of the Patent Office, the routine handling of correspondence with the public, and the proper routing of official communications relating to the processing of applications, from the time of their receipt until the jurisdiction of the Patent Office in relation to them ends. The Executive Office also has supervision of the mechanical details of the issuance of patents after the applications have been allowed, of the preparation and distribution of the publications of the Patent Office, and of the reproduction of its records. The maintenance and operation of the Patent Office Library and Search Room also are under the general supervision of the Executive Office.

The foregoing outline reveals that in order to handle patent applications cur- 
rently approximating 80,000 a year a complex organization is required. The functions of the Office, however, have been integrated in such a manner as to simplify as far as possible the functions and services that the Patent Office performs for the public.

In summary, the foregoing review of the over-all method of procedure in the processing of patent applications will serve to emphasize the purposes for which the Patent Office exists and to reveal its importance as the fountainhead from which the patent grant originates. 